\title{
O SERTÃO DE PATATIVA DO ASSARÉ. A INFÂNCIA E A ORALIDADE NA POESIA INSPIRADA NA FORMAÇÃO E CULTURA DO SERTANEJO
}

(1956 - 1978)

Hernany Donato de Moura ${ }^{1}$

\section{RESUMO}

O presente artigo se apropria da poética de Antônio Gonçalves da Silva, Patativa do Assaré, uma das grandes referências das poéticas orais, para mostrar o potencial educativo contido na voz de seu canto. A análise consolida a experiência de leitura desta poética sob a luz dos Estudos Culturais e teorias da educação, afim de proporcionar o reconhecimento lúdico e pedagógico dos gêneros orais presentes no sertão nordestino. Foram selecionadas duas obras de Patativa, "Inspiração Nordestina" (1999) cuja primeira edição é de1956 e "Cante lá que eu canto cá" (2002) lançado em 1978. Em ambas as obras foram selecionadas poesias que tratam da infância, da educação e dos duros golpes que a vida nordestina desfere na criança sem poupar sua pouca idade. Com a mesma intenção de explorar as potencialidades do processo formador da poesia de Patativa, foram selecionadas poesias que evidenciam seu modo oralizado e cantado como meio pedagógico de mostrar ao leitor dotado de escrita a cultura do sertanejo e, ao mesmo tempo, instruí-lo a partir de sua própria realidade.

Palavras-chaves: Patativa do Assaré; Poéticas orais; Processo formador; Infância; Sertão.

\section{THE INTERIOR OF THE PATATIVA ASSARÉ . CHILDHOOD AND ORAL POETRY INSPIRED BY THE TRAINING AND BACKCOUNTRY CULTURE} (1956 - 1978)

\begin{abstract}
This article appropriates the poetics of Antonio Gonçalves da Silva, Patativa do Assaré, one of the great references of oral poetry, to show the educational potential contained in the voice of his singing. The analysis consolidates the reading experience of this poetic in the light of cultural studies and theories of education, in order to provide the playful and educational recognition of oral genres present in the northeastern hinterland. Two works of Patativa were selected, "Inspiration Northeast" (1999) whose first edition is de1956 and "Sing there I sing here" (2002) released in 1978. In both works were selected poems dealing with childhood, education and the hard knocks that life strikes in northeastern child without sparing his young age. With the same intention of exploiting the potential of the forming process of Patativa poetry, poems were selected to show their oralizado mode and sung as a pedagogical means of showing the reader gifted with writing the country music culture and at the same time, instruct it to from their own reality.
\end{abstract}

Keywords: Patativa do Assaré; Oral poetic; Process trainer; Childhood; Hinterland.

O objetivo deste trabalho, enquanto abordagem interdisciplinar em educação, literatura, história e teoria cultural, incide, de certa forma, no engajamento pessoal das experiências vividas no sertão - região do semiárido baiano às margens do rio São Francisco - que se fixam na memória: o privilégio de ter nascido na rua da feira me trouxe um universo colorido, cheiroso e sonoro. Nele, histórias fantásticas, rinhas de galo, 
"retretas" (brigas) entre famílias motivavam vinganças quando a justiça fechava os olhos, "converseiro" de comadre mais comadre na calçada de casa, racionamento de energia elétrica motivado pela falta de chuvas, prosa nas bancas de feira, empulhações para homens e mancebos, caboclos, fome (morria-se de fome e de calor), índios com roupas "normais", ciganos, embolada, viola, couro, medo e respeito pelos vaqueiros, zoada e cheiro de feira...

Nos últimos anos tem-se assistido o aumento do interesse por parte de historiadores, de educadores e de estudiosos da literatura para trabalhar a partir das trajetórias individuais, sobre as quais, a tentativa de se reler o modo de viver de determinadas personagens das classes populares gera fascínio. Através dessa relação com a história, educação e narrativa, a literatura de Patativa do Assaré nos dará o suporte necessário para que possamos conhecer a trajetória de seu canto e sua legitimação no meio social e, sobretudo, descobrir que na essência de sua poesia pode-se pescar intenções de formação do sujeito sem, contudo, menor intencionalidade de ser pedagógico ou didático. Em seus primeiros versos, datados de 1956, já alerta ao leitor a rudeza de seus versos:

\author{
Ao Leitô \\ Leitô, caro amigo, te juro, não nego, \\ Meu livro te entrego bastante acanhado, \\ Por isso te aviso, me escute o que digo, \\ Leitô, caro amigo, não leia enganado. \\ É simpre, bem simpre, modesto e grossêro, \\ Não leva o tempero das arte e da escola, \\ É rude poeta, não sabe o que é lira, \\ Saluça e suspira no som da viola. \\ Tu nêle não acha tarvez, com agrado, \\ Um trecho engraçado que faça uma escôia, \\ Mas êle te mostra com gosto e vontade, \\ A luz da verdade gravada nas fôia. \\ Não vá percurá neste livro singelo \\ Os canto mais belo das lira vaidosa, \\ Nem brio de estrela, nem moça encantada, \\ Nem ninho de fada, nem chêro de rosa. \\ Em vêz de perfume e do luxo da praça, \\ Tem chêro sem graça de amargo suó, \\ Suó de caboclo que vem do roçado, \\ Com fome, cansado e queimado do só. \\ (PATATIVA DO ASSARÈ, 1999, p. 27)
}

Observa-se, em primeiro lugar, que sua escrita é marcada pela oralidade, não porque Patativa não soubesse o que é a escrita "da escola", mas porque quer evidenciar os traços de rusticidade da oralidade, onde a escrita se aproxima, ao máximo, ao modo de se falar quem lida com a roça de sol a sol. Se deixando passar como um suposto modo inferior de fazer poesia, chega ao âmago da estética de expressar a realidade do sertão. E o sertão, não é bonito ao olhar desavisado, não é cheiroso às narinas sutis e não tem sons sibilantes. É preciso suar para chegar na poesia desse lugar e dessa identidade.

Essa busca pela trajetória individual - penso eu - como uma tentativa de reconstruir o interior das personagens, no qual se exploram sentimentos e desejos, nos ajuda de 
diversas maneiras: em primeiro lugar, o fluxo que circunda o elo entre literatura, educação e história, como meio de estabelecer uma conexão com a memória do autor; em segundo plano, estabelecer como e de que modo sua produção poética reflete na formação da consciência popular que ultrapassa as fronteiras regionais, pois a partir de sua "aldeia" são construídas narrativas poéticas de teor universal.

A trajetória de Antônio Gonçalves da Silva (1909-2002), o Patativa do Assaré, permite a esta análise um olhar profícuo que concebe outra visão da história social, em que destacamos as questões econômicas, as relações sociais e a ausência de política de educação sistematicamente exercitada no interior do nordeste brasileiro aos olhos de sua produção poética e pelo testemunho de suas narrativas orais.

A imersão no universo narrativo do sertão de Patativa do Assaré faz com que relembremos as experiências colhidas na infância. Essas narrativas populares apresentam vestígios sociais representados no que conhecemos como herança cultural. A pesquisa pretende trazer à luz do debate em educação a relação didática-pedagógica das poéticas orais, meio esquecida, no contexto de formação da sociedade sertaneja do Nordeste brasileiro no século XX. Assim, a infância em Patativa é representada pela formosura, afetividade pela criança, por suas brincadeiras intimamente ligadas à natureza e que, depois se desfaz com os duros golpes da pobreza imposta à infância do sertão. Em "A morte de Nanã” (1978, p. 38) a formosura e o amor se expandem na dor:

Eu vou contá uma história Que eu não sei como comece, Pruquê meu coração chora, A dor no meu peito cresce, Aumenta o meu sofrimento E fico ouvindo o lamento De minha alma dolorida, Pois é bem triste a sentença, De quem perdeu na existência $\mathrm{O}$ que mais amou na vida.

Já tô véio, acabrunhado, Mas em riba deste chão, Fui o mais afortunado De todos filhos de Adão. Dentro da minha pobreza, Eu tinha grande riqueza:

Era uma querida filha, Porém morreu muito nova.

Foi sacudida na cova

Com seis ano e doze dia.

Morreu na sua inocência Aquele anjo encantadô, Que foi na sua existência, A cura da minha dor E a vida do meu vivê. Eu beijava, com prazê, Todo dia de manhã, Sua face pura e bela. Era Ana o nome dela, 
Mas eu chamava Nanã.

Nanã tinha mais primô

Do que as mais bonita jóia,

Mais linda do que as fulô

De um tá de Jardim de Tróia

Que fala o doutô Conrado.

Seu cabelo cacheado,

Preto da cor de veludo.

Nanã era meu tesouro,

Meu diamante, meu ouro,

Meu anjo, meu céu, meu tudo.

Onde os olhos viciados da pedagogia liberal vê o infortúnio como responsabilidade da ignorância do homem do povo, Patativa o reinterpreta em amor profundo descrito aos detalhes em cada característica de Nanã. Traduz, desse modo, a cultura sertaneja que cuida de sua infância e da forma prazenteira em vê-la brincar, ou seja, em ser criança.

Em "A menina da cajazêra" (1978, p. 195) reencontramos a íntima relação da infância sertaneja com a natureza:

\section{$[\ldots]$}

Bem juntinho de casa

A cajazêra nasceu,

Linhêra, iguá uma frecha,

No rumo do céu cresceu.

Era franzina, dergada,

Mas a copa arredondada

Não podia havê maió.

Quem reparava, dizia

Que a mêrma só parecia

Um grande chapé de só.

Entounce a linda criança,

Aquela boa menina,

Era o prazê e era a paz

Da cajazêra franzina.

Naquela sombra vevia,

Durante as horas do dia

Não se afastava dali,

Sempre contente, brincando,

Cheia de vida, zelando

Os seus brinquedos infantí.

Aquela copa vistosa

Pra inocente criança

Era um céu, um paraíso

Verde, da cô da esperança.

As ave fazia festa,

Tinha graça a doce orquesta

Daqueles musgo de pena,

Com seus requebrado canto, 
Lovando o riso e o encanto

Daquela santa pequena.

Se o vento vinha de longe,

Todo amoroso, brincá,

Encrespando na lagoa,

As água cô de cristá,

Na cajazêra chegando

Era tão macio e brando

Cumo quem faz a escóia

De um amô e de um carinho,

Soprando devagarinho

Mode não derrubá fôia.

Tudo quanto era bondade,

Paz, inocença e beleza,

Vinha ali fazê morada

E de toda essa riqueza

A menina era a rainha,

Dava a entendê que Deus tinha

Pra o nosso mundo de increu,

Em favô daquele sito,

Mandado lá do infinito

Um pedacinho do céu.

Se em cima, na verde copa,

A passarada cantava,

Em baxo, na fresca sombra,

A criançinha brincava.

Aquela arve tão amiga,

Caridosa, sem fadiga,

De tudo era a potreção.

Sua copa arredondada

Vivia sempre enfoiada,

Que fosse inverno ou verão.

Eleger a criança como mote da poesia é, do mesmo modo, rebater em sua educação, mas não a educação escolar, pois essa, nos rincões do sertão não se fez realidade pela ausência quase completa de grupos escolares. Patativa fala de uma educação dos elos familiares, do vínculo com a natureza e dos duros golpes de crueldade que não poupa a infância. Em "A morte de Nanã" (1978) o sentimento de luto pela morte da menina devido fome provocada pela seca que grassava o sertão nas décadas de 1950, 60 e 70. Ainda que o pai, em última tentativa, oferecesse caça do mato e o beiju de mucunã².

Já no poema "A menina da cajazêra" (1978) o golpe não recai sobre seu frágil corpo infantil, mas não menos cruel, lhe impõe a orfandade. Sozinha no mundo a menina abandona o seu local de vivência e morada como é próprio dos movimentos migratórios, quando a esperança e o sentido de pertencer se esvaziam de seu próprio significado. Como provada rudeza, Patativa passa a narrar a morte da cajazeira por causa da dor e ausência da menina. Revela, assim, a simbiose do sertanejo com a natureza na mais tenra infância.

A "Seca de Quinze" (1915) chega de forma intensa, fazendo com que novas levas de sertanejos retomassem os caminhos dos grandes centros urbanos à procura de apoio e reivindicando condições básicas de sobrevivência. Visando a proteção das cidades mais 
desenvolvidas e com estrutura urbana em crescente processo de evolução, diversos foram os governantes que criaram espaços destinados ao "confinamento" dos retirantes, conhecidos também como campos de concentração. Geralmente superlotados, os campos funcionavam como espaços disciplinadores, que evitavam o descontrole do Estado sob o pretexto de uma "distribuição de alimentos e o atendimento de enfermos [...] o campo se transformou num local para onde os retirantes iam apenas para morrer". (NEVES. 2000, p. 87). Mesmo com os avanços das campanhas de vacinação, o excesso de retirantes e o insuficiente número de vagas possibilitaram diversos surtos de epidemias decorrentes da falta de princípios básicos de higiene.

Nesse momento a irregularidade de chuvas no Nordeste ainda é vista como um problema de natureza climática, que faz aflorar um conjunto abrangente de problemas sociais, os quais fazem abrir os olhos das instâncias de poder, a partir das reivindicações da população, para alertar também a persistência de fatores políticos para questão do semiárido. Contudo, nota-se a transferência no modo de ver tal problema por meio das perspectivas da linguagem, que se moldam de acordo com as situações, pois o sertanejo passa a ser visto e tratado como flagelado, ao invés de retirante. Mudança de paradigma que reflete uma condição maior de fragilidade desse sertanejo, que insiste em sobreviver. (NEVES, 2000, p.89)

Antônio estreita paulatinamente sua relação com aquele ambiente natural, ora hostil, ora idílico, muito particular e o toma como seu. Da sua infância aos seus setenta anos de idade sempre se orgulhou de ter "botado roça", fato que edifica um jeito próprio de se expressar nitidamente presente em seu legado. A serra de Santana se concretiza em seu mundo, o cheiro que a terra e o mato bafejam, unido à sinfonia ininterrupta dos pássaros, deixa o menino Antônio preso na inquietude e também traz consolo para aquele jovem. Junto com seu irmão mais velho, o Zezé, saía pelo mato a fim de caçar algum animal para somar à ceia, porém Antônio imergia nas imitações de violeiros famosos e nas edificantes histórias de cordel. Seu desejo está transposto nos versos do poema "Serra de Santana" (1978, p.239) que relata poeticamente as características marcantes do espaço que traz à tona suas reminiscências e sua origem:

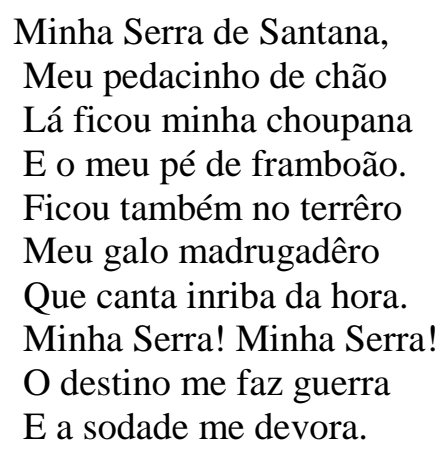

São versos que trazem a importância de um ambiente, que aparece como forma imprescindível para a formação concreta de sua produção poética. Nesse sentido, à luz do pensamento de Aristóteles notamos a imitação dos meios e do objeto:

Do mesmo modo que alguns fazem imitações segundo um modelo com cores e atitudes, - uns com arte, outros levados pela rotina, outros enfim com a voz; assim também, nas artes a imitação é produzida por meio do ritmo, da linguagem e da harmonia, empregados separadamente ou em conjunto. [s.d] (BOSI, 1998, p.239). 
A partir do ritmo, Antônio adentra o universo que vai construindo um arcabouço próprio, no qual a estética das coisas que vê e imita se junta ao que consegue captar também pela audição: o som, a voz, o canto, a sequência didática imposta por suas narrativas trarão ao futuro poeta um leque de possibilidades de criação.

Em 1921, aos 12 anos frequenta a escola por apenas um semestre, na qual por meio das cartilhas de Felisberto Rodrigues Pereira de Carvalho, editadas entre 1892 a 1959, pela Livraria Francisco Alves (CARVALHO, 2008, p.18), descobre a importância da leitura. Embora o professor tivesse uma relação carinhosa com os alunos, sua fragilidade era demonstrada pela sua falta de preparação, o que dificultava o aprendizado principalmente em aulas de pontuação. Esse fato proporcionou a Antônio marcar sua pontuação a partir do ritmo das palavras e de sua voz (DEBS, 2000, p.15), representando traços fundamentais para as "marcas da oralidade". O menino Antônio aprendia a juntar as letras com facilidade e dedicava-se à leitura solitária dos folhetos de cordel ou ficava escutando seu irmão Zezé em suas performances de leitura. Ainda criança ensaiava os seus primeiros versos.

Trabalhar a importância da voz na poesia popular nos conduziu àquele exercício com a palavra realizado na infância. Não faria sentido, somente, associar a este trabalho uma motivação teórica, pois, após algumas leituras sobre folcloristas que são referências e outras acerca da proposta política dos Estudos Culturais, nos deparamos com a necessidade de aproximação com o universo das poéticas desenvolvidas e executadas por vias orais.

A dimensão do exercício da oralidade, em Patativa do Assaré, retrata a construção do seu sertão a partir da importância pedagógica que sua voz alcança, pela substância sonora do cantador. Esta figura representa a riqueza das poéticas orais e empresta a autoridade de seu canto para outros agentes sociais de comum importância para a concretização do sertão de possibilidades. Ainda aqui, colocamos a diferenciação dos tipos de oralidade, com relação ao legado do poeta e a força da performance como característica primordial da literatura e culturas orais.

Enfim, sabemos que o universo que diz respeito à cultura oral e suas manifestações, a literatura oral, é um campo movediço, pois nos deparamos com a movência de suas estruturas poéticas e com a polissemia que as palavras-faladas assumem a depender das respostas do público e das circunstâncias. Entretanto, o trabalho das poéticas orais sob a perspectiva da voz/canto, que, no Brasil, ainda se estabelece pela égide das correntes europeias que se apoiam no medievalismo, é, em si, um processo pedagógico para o leitor ou ouvinte que se dispõe a ler ou ouvir o poema Patativa do Assaré.

Pensamos que a postura precise ser revista para desfazer, mais uma vez, o preconceito com relação à literatura popular. Estudar a cultura popular sob o viés da literatura nos faz enxergar a memória e as peculiaridades educacionais da complexa identidade sertaneja.

\section{1-Romanceiro Popular do Nordeste: um exercício pedagógico necessário.}

Quando falamos em literatura nos vem logo à cabeça o texto escrito, geralmente preso a um livro com brochura e capa impecáveis. Quando pensamos em literatura nos aparece também a lembrança das grandes ilhas editoriais abarrotadas de intelectuais que 
primavam por uma postura, muitas vezes, transcendental de um fazer literário. A literatura que é divulgada pela "alta cultura" não condizia com a realidade da cultura popular, que se sentia distanciado daquelas histórias, principalmente pela falta de atenção aos seus costumes e a sua linguagem. Desse modo, Câmara Cascudo (1978, p.26), desmistifica a relação entre as maneiras de conduzir o fazer literário:

A literatura que chamamos de oficial, pela sua obediência aos rigores
modernos ou antigos de escolas ou de predileções individuais, expressa
uma ação refletida e puramente intelectual. A sua irmã mais velha, a
outra, bem velha e popular, age falando, cantando, representando,
dançando no meio do povo, nos terreiros das fazendas, nos pátios das
igrejas nas noites de novena, nas festas tradicionais do ciclo do gado, nos
bailes do fim das safras de açúcar, nas salinas, festa dos padroeiros,
potirum, ajudas, bebidas nos barracões amazônicos, espera de Missa do
Galo; ao ar livre, solta, álacre sacudida, ao alcance de todas as críticas de
uma assistência que entende, letra e música, todas as gradações e
mudanças do folguedo.

Pelas vozes de trabalhadores rurais, donas de casa, vaqueiros, cantadores, cegos de feira e poetas populares, as manifestações literárias do interior nordestino afloram no "estalar de dedos", fazendo aparecer reminiscências da infância. No sertão nordestino, onde as estruturas poéticas e os motes ibéricos se fixaram, o sertanejo desenvolveu com habilidade o respeito à palavra. Não é mérito sertanejo a utilização da palavra falada, pois fora na Grécia Antiga que a cultura oral construiu seu marco epistemológico. As obras (Ilíada e Odisséia), cuja importância definiu a pedra fundamental da civilização ocidental são atribuídas a Homero. No entanto, a influência da tradição oral é comumente associada pelas elocuções dos aedos, que, por meio de seus versos, traduziam os feitos heróicos de um povo.

Seja na Antiguidade Grega seja no início do século XX no sertão brasileiro comungamos da mesma necessidade com o trato oral. A valorização da cultura oral se faz fundamental, não somente, quando ensaiamos qualquer estrutura poética em sala de aula, mas é de grande importância para elaboração de sintagmas nominais, verbais e também na construção de simples ou elaboradas sentenças da nossa própria linguagem. A fundamentação dos ritmos e desenvolvimento de sequências didáticas contidas nas narrativas orais trazem ao ouvinte uma autonomia linguística e um raciocínio perspicaz, que causam admiração a qualquer leitor bem instruído. Fica permanentemente longe desse trabalho a perspectiva de exclusão de uma cultura de escrita, porém ressaltamos aqui o anseio de que ambas as culturas se completam.

Diante dessa necessidade de encontrar a importância dessa cultura oral observamos no poema "Mãe Preta" (1978) o carinho que uma remanescente de escravo proporciona na vida de uma criança filha de fazendeiros, que fora criada por "sua Mãe Preta" (2002, p. 95 6) desvendando os jogos linguísticos do carinho, do afago dos brinquedos orais e da primeira educação. Nele encontramos:

Quem pela infança passou, O meu dito considera,

Eu quero, com grande amô, Dizê Mão Preta quem era.

-Mãe Preta dava impressão

Da noite de escuridão,

Com seus mistero profundo, 
Escondendo seus praneta;

Foi ela a preta mais preta

Das preta qui eu vi no mundo.

[...]

Quando as minha brincadêra

Causava contrariedade

A minha mãe verdadeira

Com a sua otoridade,

As vez brigava comigo

E num gesto de castigo,

Botava os óio pra mim,

Mas porém, não me batia,

Somente pruque sabia

Qui Mãe Preta achava ruim.

[...]

Por isso eu não tinha medo,

Sempre contente vivia

Mexendo nos meus brinquedo

E fazendo istripulia.

Dentro de nossa morada,

Pra mim não fartava nada,

O meu mundo era Mãe Preta;

Foi ela que me ensinou

Muntas cantigas de amô,

E brincá de carrapeta.

Nota-se no excertos acima que existe uma relação de importância materna exaltada pela figura da Mãe Preta sempre colocada não somente pelas grafia das letras maiúsculas, todavia à atribuição de importância atribuída na própria família. Por viver em constante diálogo e transmitindo uma série de gêneros textuais próprios da oralidade, como as "cantigas de amô", Mãe Preta tenha um papel que mistura a "inventação" com diversas sequências didáticas, que seriam comuns a todo e qualquer educador nos anos iniciais da formação escolar.

Pela etimologia que a palavra traz, a literatura, em seu sentido mais integral, significa letra. Logo se cria um impasse frente ao complexo significado que a expressão literatura oral incita. Algumas visões sobre a expressão contribuem para mostrar o jogo semântico, que alimenta a contradição entre as palavras que compõem o termo literatura oral.

Câmara Cascudo, pesquisador dos saberes do povo nordestino, teve em sua região a matéria-prima para melhor fundamentar e entender as manifestações culturais do nordeste brasileiro, colocando em pauta as influências ibéricas e a criatividade edificada na cultura. Segundo ele, a ideia relacionada ao termo, além de estar diretamente preocupada com uma valorização dos saberes do povo, reflete uma significação universal e demonstra uma preocupação geralmente associada ao sentimento coletivo.

Para Cascudo (1978, p.28), na literatura oral, compreendem algumas estruturas de fácil assimilação transpostas nas rezas, nas danças de rodas, nas estórias, danças cantadas, danças de divertimento coletivo, rondas, "brinquedos infantis", nas cantigas de embalar, nos versos das antigas xácaras e no canto popular e tradicional. Para ele, a literatura oral brasileira:

[...] se comporá dos elementos trazidos pelas três raças para a memória e uso do povo atual. Indígenas, portugueses e africanos possuíam cantos, danças, estórias, 
lembranças guerreiras, mitos, cantigas de embalar, anedotas, poetas e cantores profissionais, uma já longa e espalhada admiração ao redor dos homens quem sabiam falar e entoar.

Conhecida como o primeiro leite da cultura humana, a literatura oral abrange as relações sociais atinentes ao povo, quando, de forma didática, traduz informações de modo mais acessível, mantendo o vínculo entre memória e atualidade, sem deixar de lado as práticas de lazer que as estruturas orais proporcionam.

A cultura oral se manifesta, geralmente, por meio de seus guardiões. Os idosos são reconhecidos como os maiores transmissores destes tipos de manifestações, pois absorve tudo aquilo que fora assimilado durante a infância, como se os adultos e jovens tivessem muito preocupados com "as coisas práticas do mundo". As crianças assimilam com facilidade os conhecimentos passados pelos avôs ou pessoas mais velhas (TAVARES, 2005, pp.105-106).

Mesmo assim, a literatura oral, segundo Cascudo, amplia sua disseminação alcançando outros horizontes de atuação. Todavia, mantém suas características fundamentadas diante das perspectivas da oralidade. Mediante a necessidade de novas formas de leitura, a literatura oral se apropria de novos métodos de "publicação", dentre os quais:

[...] a reimpressão dos antigos livrinhos, vindos de Espanha e Portugal e que são convergências de motivos literários dos séc. XIII, XIV, XV, XVI, Donzela Teodora, Imperatriz Porcina, Princesa Magalona, João de Calais, Carlos Magno e os Doze Pares da França, além da produção contemporânea pelos antigos processos de versificação popularizada, fixando assuntos de época, caça, amores, incluindo a poetização de trechos de romances famosos tornados conhecidos, Escrava Isaura, Romeu e Julieta, ou mesmo criações no gênero sentimental, com o aproveitamento de cenas ou períodos de outros folhetos esquecidos em seu conjunto (CASCUDO, 1978, p.22).

Vale lembrar que, mesmo com a inserção de novas formas de leitura da literatura oral, devido à impressão das histórias contadas, para a cultura oral, não existe uma versão oficial ou original, tudo se copia, transforma-se. "Como tudo é feito na base da memória, cada versão é diferente da anterior" (TAVARES, 2005, p.106). A literatura oral é representada naquele instante, pois depende do desempenho do narrador em um determinado momento.

Para o escritor paraibano, Ariano Suassuna (1974), a poesia popular produzida no Nordeste brasileiro compõe uma estrutura bem maior do que pensamos. De acordo com sua definição, no "Romanceiro popular do Nordeste" estão dispostas suas mais variadas formas de representação poéticas da cultura popular nordestina. No Romanceiro Popular descrito por Suasuna (op.cit.), encontramos dois grupos: no primeiro, encontramos a poesia improvisada, na qual temos a recorrência de uma literatura fundamentada na cultura oral; o segundo grupo se detém a trabalhar com a literatura de cordel e de tradição oral decorada.

Neste primeiro grupo, da poesia improvisada, temos a inserção do repente, da embolada, do coco de improviso, dos aboios de vaqueiros e das demais manifestações executadas de súbito, estabelecidas pelo acompanhamento de uma métrica trazida da tradição ibérica, mas que aqui se desenvolveu assumindo suas propriedades. De acordo com tais contribuições para o exercício da poética de improviso sertaneja, a sextilha e a décima e, por conseguinte, seus derivados são as estruturas mais comuns neste tipo de 
poesia. É bem verdade que a estrutura desenvolvida na poesia de improviso tem uma próxima ligação com os livrinhos da literatura de cordel, com pelejas e histórias de caso pensado.

Para Suassuna (op.cit.), a "escola do Teixeira" fora uma grande opção para que os cantadores desenvolvessem sua arte, ampliando as possibilidades de desenvolver seus versos e novas formas de organizar estrofes. Assim, Suassuna relata a importância de determinas estruturas poéticas e da referência de cantadores afamados:

\begin{abstract}
A estrofe mais importante no campo da poesia improvisada dos Cantadores - e também nos "folhetos" dos Poetas populares - é a "sextilha", ou "repente". Foi, ao que se diz, introduzida no Romanceiro pela "Escola do Teixeira", da Vila do Teixeira, na Paraíba, onde pontificou o mestre dos Cantadores nordestinos, aquele que deu personalidade e "legitimidade" ao Cantador - Francisco Romano Caluete, mais conhecido como Romano Teixeira ou Romano da Mãe-Dágua. [...] De fato, porém, a sextilha, forma muito simples de estrofe, já era usada na poesia medieval portuguesa. O papel de Francisco Romano deve ter sido o de fazer os Cantadores nordestinos abandonarem a "quadra", usada anteriormente e hoje abandonada, e passarem a usar a sextilha, que é uma estrofe de seis versos de sete sílabas, rimados na disposição $\mathrm{ABCBDB}$ - as letras iguais correspondendo às rimas iguais. (1974, p. 169)
\end{abstract}

A Literatura de cordel, colocada por Suassuna como mais um tipo de estrutura, que compõe o Romanceiro Popular do Nordeste, tem uma produção que apresenta seus primeiros registros nos fins do século XIX. Ela é considerada uma fonte de aprendizado como cartilha de alfabetização, suporte para o entretenimento e meio de informação sobre os costumes, que representam a identidade das comunidades do interior do Nordeste, nas quais a ideia de isolamento desenvolveu no sertanejo, "invulgar capacidade de enfrentar as adversidades históricas e sociais com elevado sentido poético" (SANTOS, 1987, p.5).

As representações, que o Romanceiro popular imprime, fazem valer a força de uma literatura inspirada nas histórias de cunho coletivo, referenciada pelo que existe de mais íntimo nos sentimentos do povo, executadas por uma grande força comunicativa, nas quais os desejos coletivos deste povo são explorados. Por este motivo as histórias da cultura ibérica e da cultura sertaneja se confundem em sua origem e também na sua divulgação, quando veiculados pelo Romanceiro, e mais precisamente, na literatura de cordel, trazendo à tona fusão entre o erudito e o popular.

No livro "Cante lá que eu canto cá - Filosofia de um trovador nordestino" (1978), Patativa do Assaré (2002), recorre à voz da personagem do "Puxadô de roda" (1978), figura necessária no desenvolvimento do trabalho nas casas de farinha, o qual tinha por função não deixar que o ritmo da produção caísse a partir da elocução de poesias e de narrativas, nas quais estavam inseridos ensinamentos de uma vida calcada na coletividade e no trabalho. Assim, é flagrante observarmos a relação entre tradição e modernidade na primeira estrofe do poema:

\title{
$[\ldots]$
}

Seu moço, eu peço perdão,

Não tenha raiva de mim,

Mas a civilização

Faz coisa que eu acho ruim;

Os engenheiro mecano,

Francês, inglês, mericano,

Se larga de seus coidado 


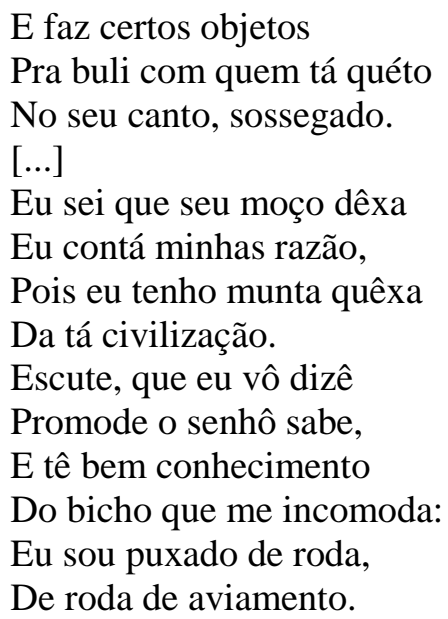

Embora o senso comum relegue a invenção dos desafios ao sertão nordestino, Câmara Cascudo relata que tais modalidades existiam na Grécia, mais especificamente, na contenda entre pastores, a qual era composta de forma alternada e que os contendores respondiam em número igual de versos. Cascudo ainda afirma: "A técnica de canto amebeu fora empregada por Homero na Ilíada, I, 604, e na Odisséia, XXIV, 60.” (2000, p. 176).

No canto amebeu, disputa poética entre bufões, tenson, percebe-se a semelhança através do clima de disputa e combate com o desafio tão conhecido no Nordeste brasileiro. Inclusive o nome "desafio" nós herdamos de Portugal, onde a modalidade poética foi assimilada com mais facilidade pelas camadas populares. Na construção do Brasil temos ainda interferência dos cantos indígenas. Cascudo alerta-nos para a facilidade narrativa e de comunicação que os africanos nos trouxeram através de suas loas. (2000, p.183)

Os abecês em sua origem exerciam uma função mnemônica, sob a qual exercício didático, para uma maior aprendizagem era desenvolvido por jesuítas em boa parte das suas missões no Brasil. Cascudo destaca a força narrativa que contavam as estórias de animais astutos, que criavam fama em determinadas localidades. Contudo, o pesquisador mostra a pouca utilização da modalidade e inexistência dela em prosa $(2000$, p.70). $\mathrm{Na}$ segunda metade do século $\mathrm{XX}$, os abecês traziam a recorrências de temáticas do ciclo religioso, mas, devido à recorrência das estiagens, a seca e o flagelo tornaram-se comuns a este tipo de estrutura.

Estas famílias-base servem como alicerce para que possamos entender melhor a lógica da poesia edificada por Patativa do Assaré, nas obras aqui selecionadas, pois nelas encontramos exemplos da poesia clássica e também romântica, mas, principalmente, a influência das práticas encontradas no Romanceiro Popular do Nordeste. Sua poesia oscila entre as estruturas de "bancada" mais comuns, da mesma forma que lançava em praças, nas rádios, discos e também mostrado em algumas produções cinematográficas seus improvisos. O caráter popular da poesia oralizada torna fonte de informação e de formação do homem sertanejo na medida em que sua presença é constante nos lares, nos locais de trabalho, na labuta com a terra e com o preparo do alimento. Cumprindo, então, a imersão desses nas primeiras letras e no registro de sua cultura através de uma literatura que circula entre os pares.

O segundo tipo de literatura destacado por Cascudo refere-se ao anonimato e à transmissão oral desta modalidade, na qual perfaz um itinerário que circula entre anedotas, facécias, contos de fadas, advinhas, autos e desafios. Assim, a literatura oral se configura pelo "boca a boca" de acordo com a mais curiosa necessidade. 
Já a literatura popular está representada tanto pelo material impresso, muito bem apresentada a partir dos folhetos de cordel, quanto pela elocução de cantadores nas pelejas e desafios, sendo estes importantes expoentes dos versos cantados ou necessariamente anônimos.

\section{Considerações finais}

Na organização deste trabalho trago uma inquietação fruto ainda da época de minha graduação em Letras, na qual não entendia o porquê de não estudarmos aspectos relevantes da cultura brasileira, quiçá do Nordeste. Estranhava a não inclusão nos conteúdos destas formações tão nossas, próximas, mas distantes daquele contexto proposto pela academia. Não entendia também a exaltação aos elementos da cultura europeia, americana e, até mesmo do Sul do Brasil, em detrimento de um pré-julgamento dos valores culturais que sempre foram mais próximos do nosso contexto sociocultural.

Concepções precipitadas e movidas pela falta de informação, sobre as quais se erigiam afirmações diversas: parafoclórico, paradidático, paraliteratura, literatura menor e de mau gosto, literatura marginalizada. Como era difícil debater sobre a beleza desta cultura com os Senhores em seus templos.

Vimos, aqui, o desenvolvimento das concepções acerca da cultura, da literatura, da formação do sertanejo e de cultura popular, que nos foram passadas no percurso de séculos, com as quais ditaram padrões morais que caracterizam os preceitos sociais que ensina ao homem sem escola, suas lições fundamentais de vida ainda hoje.

Cultura, literatura e formação humana foram conceitos que fazem referência direta aos costumes e anseios das elites e, principalmente, da emergente burguesia. Apoiada a estes princípios, a crítica literária e as instituições acadêmicas acatavam valores, que conforme a classe social eram aceitos ou rejeitados pelos respectivos julgamentos. A crítica artística (literária) tinha neste momento a função "eclesiástica" de estabelecer ou não a entrada de determinada obra e de seu autor no "templo". Imprimatur!

Mesmo com toda a perspectiva "sacra" destinada aos conceitos acima, a teoria cultural possibilitou um olhar além das linhas do "sagrado", além das margens dos templos. Ela permitiu ao homem moderno a possibilidade de ouvir a história contada pelas populações mais carentes, as quais as portas destas instituições estavam sempre fechadas. A história formada pelos grupos sociais desfavorecido difere substancialmente daquela contada pelo Estado, principalmente na sua transmissão. Nela, as transmissões elaboradas pelos populares dificilmente trazem a sacralização da palavra escrita, pois os processos de reiteração fundamentavam uma das principais características das culturas orais. A sensação que temos que o universo representado pelas manifestações da cultura oral é geralmente representado por julgamento não especializado.

Neste horizonte da cultura oral elencamos a importância do complexo campo literário e deformação educativa do homem comum, no qual encontramos a estrutura do Romanceiro Popular do Nordeste brasileiro, cujas influências da cultura ibérica foram recriadas com o passar dos tempos. Bráulio Tavares (2005), ao comparar o mundo da escrita e mundo da cultura oral, descreve que, no primeiro caso, existe uma rigorosidade acadêmica para se achar a versão oficial, aquela que deverá ser publicada. Na cultura oral tudo é cópia, pois existem várias versões para a mesma obra, para o mesmo mito, para a mesma lenda. Aqui, tudo depende da capacidade criativa do poeta e da situação, pois não existe uma maneira de aprisionar esse tipo de produção.

$\mathrm{Na}$ cultura do Cariri cearense, observei a influência explícita da oralidade. Seja ela exercitada nas formas primárias, perfazendo estruturas que desconhecem os grafismos da 
escrita, seja através das influências da oralidade nos processos de escrita, ou ainda, quando esta mesma oralidade reaparece por meio da mídia eletrônica. Neste último caso, o interesse maior refere-se às possibilidades de documentação e da memorização, nas quais se perde a pluralidade performática dos textos orais, delegando-os a uma única performance que pode ser repetida inúmeras vezes de forma fixa. Esta oralidade mediatizada tem seus méritos para o arquivamento das obras vocais, porém elimina a movência e versatilidade das práticas orais.

Patativa do Assaré viveu mais de noventa anos em pleno século XX. Herdou o tradicionalismo da região do Cariri cearense, no qual o catolicismo primitivo e os movimentos messiânicos alimentavam a esperança dos sertanejos na tentativa de aliviar a aridez vivenciada por boa parte da população desenganada. O poeta é testemunha dos períodos de estiagem, da arrogância e da exploração política de fazendeiros-coronéis, os quais mantinham a rede de exploração do camponês para assegurar a estrutura de pobreza e de êxito nos pleitos eleitorais. Numa rara capacidade de solidarizar-se com a dor do outro, canta a rudeza da vida do sertão nordestino, onde nada e ninguém são poupados do mal trato, porém e sobretudo, sob a dor do flagelo faz emergir o afeto, a beleza e canto de se orgulhar de se ser o que é: um sertanejo.

Nas poucas lições que obteve no grupo escolar assimilou e desenvolveu o trato com a palavra poética, com a qual teve competência para edificar, ao seu modo, a estrutura social que vivenciou em sua trajetória de vida. De acordo com a influência das tradições populares encontradas no Romanceiro Popular, o poeta desenvolve habilidades na arte da cantoria, fato que influenciou boa parte de sua poesia. Entretanto, o desejo pela leitura fez com que ele entrasse em contato com obras universais, a exemplo de Luis de Camões, das ideias de liberdade veiculadas pelo romantismo de Castro Alves, do socialismo de Marx, a partir das quais sua obra sertaneja adquire características universais. $\mathrm{O}$ sofrimento e a realidade do camponês nordestino ou do operário nos grandes centros urbanos podem ser semelhantes aos indivíduos de outros países, que comungam da mesma estrutura das culturas orais.

Patativa do Assaré viveu por quase um século e presenciou mudanças de certos paradigmas. Desenvolveu sua poética por vinte e cinco anos de forma oral, sem o auxílio do papel. Esta percepção trouxe a sua poesia uma carga performática, a qual caracteriza a literatura oral, comum na formação da cultura popular e observada nos mercados, nas vendas, nas festas de populares e nos brinquedos infantis. A partir da concepção da poesia que ressoa entre corpos (emissor - receptor), ele resgata no primor de sua obra, em pleno vapor do modernismo, a importância da voz e a legitimação da palavra pelo canto. A sua poesia desfaz o sigilo/silêncio das pessoas comuns, porque quebra com o monopólio da palavra. Não é à toa que as canções de protesto, na América Latina, retomam a autoridade da voz e enaltece a figura do cantor.

A sua voz acompanhada da viola que preenchia os espaços na região da serra de Santana - povoado da pequena Assaré - alcançou as festas de casamentos e reuniões familiares entre os serranos. Posteriormente ganha proporções maiores pela força das rádios difusoras, fato pelo qual recebe o convite para que seus versos assumam o formato impresso. Para refletir sobre a trajetória deste poeta-roceiro levamos em conta o processo de que a "voz", literalmente, antecede à sua escrita. Assim, encontramos o fio condutor que traz à sua obra as peculiaridades já elencadas na literatura oral. Não quero aqui afirmar que a obra de Patativa do Assaré é uma manifestação plena da literatura oral. Mas nela encontramos subsídios concretos, nos quais elementos da poesia de improviso, fundamenta-se pelo trato com performance, com a movência transferindo múltiplas aplicações/interpretações ao texto. 
O seu curioso legado poético transportado pela substância sonora ganha primordialmente a mediação eletrônica (rádios e vídeos), para posteriormente compor o formato impresso. Por este motivo, em seu legado foram assimiladas e exercitadas as diferentes formas de oralidade, do primitivo ao mais moderno para sua época. Tomando esse caminho, Patativa do Assaré faz da sua produção literária o território das suas memórias e da memória coletiva, sejam elas narrativas, sejam elas traumáticas, sejam elas afetivas, sejam elas sensoriais.

Suas memórias expostas nos seus versos configuram o seu ser tão particular, porém se apresenta dando voz ao sentimento coletivo. Na figura do cantador, a palavra se expande preenchendo as lacunas e os vazios daqueles "homens comuns", emprestando a autoridade, que outrora servia aos homens não-comuns, aos que ficavam à margem dos conceitos edificados no congelamento da cultura burguesa. Pela sua palavra rompemos a visão alienadora, na qual a cultura da classe dominante coíbe a imaginação criadora que sustenta as narrativas nacionais. Vemos no decorrer de sua obra uma intensa re(l)ação com o contexto nacional. Nessa perspectiva o poeta denuncia o seu sertão possível, no qual dissimula inferioridade e fustiga os valores dominantes. Nele o seu sertão aparece a partir da força e da utilização do verbo pelos agentes peculiares da sua cultura, no caso específico, o "cantadô", o trovador, o menestrel representam o elemento de sabedoria, também de autoridade, que fora herdado de outras escolas literárias, mas principalmente estabelece um caráter sedutor à palavra cantada, a partir do qual este sertão se torna um espaço de trocas e de conquistas possíveis. Seu sertão plausível se estabelece diante da peculiar substância sonora sertaneja, não importa se por lá, se por cá ou por estabelecer esta confluência de acordo com sua mais concreta possibilidade: o canto.

\section{Referências}

ASSARÉ, Patativa do. Cante lá que eu canto cá-Filosofia de um trovador nordestino. $2^{a}$ ed. Petrópolis: Vozes, 1978.

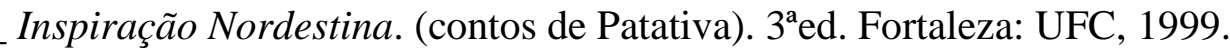

BOSI, Alfredo. Céu, inferno- Ensaios de crítica literária e ideológica. São Paulo: Ática, 1998.

CARVAlHO, Gilmar de. Patativa do Assaré: Um poeta cidadão. $1^{\text {a }}$ ed. São Paulo: Expressão Popular, 2008.

CASCUDO, Luis da Câmara. Literatura oral no Brasil. 2 ed.- Rio de Janeiro: J. Olympio; Brasília: INL, 1978.

Vaqueiros e Cantadores: Folclore poético do sertão de Pernambuco, Paraíba, Rio

Grande do Norte e Ceará. Rio de Janeiro: Ediouro, 2000.

DEBS, Sylvie. Patativa do Assaré uma voz do Nordeste. São Paulo: Hedra, 2000.

NEVES, Frederico de Castro. A seca na história de Ceará. In SOUZA, Simone de (Org.). Uma nova história do Ceará. Fortaleza: Edições Demócrito Rocha, 2000. p.76-101. 
SANTOS, Olga de Jesus. O Cordel - Testemunha da História do Brasil. Rio de janeiro: Fundação Casa de Rui Barbosa, 1987.

SUASSUNA, Ariano. Seleta em Prosa e verso. Rio de Janeiro: José Olympio, 1974.

TAVARES, Bráulio. Contando histórias em versos - Poesia e Romanceiro Popular no Brasil. São Paulo: Editora 34, 2005.

\footnotetext{
${ }^{1}$ Mestre em Letras pelo Programa de Pós-Graduação em Letras da Universidade Federalde Sergipe (2011). Professor das Faculdades Integradas de Sergipe - FISE.

${ }^{2}$ Mucunã ou olho-de-boi é uma semente de cipó comum na região

Recebido: julho-15 Aprovado: agosto-15
} 